\title{
EL PINTORESCO CASO DE LOS «PIES FORZADOS»
}

\author{
THE CURIOUS CASE OF «PIES FORZADOS»
}

\author{
Alexis Díaz-Pimienta \\ Cátedra Experimental de Poesía Improvisada \\ del Instituto Superior de Arte (Cuba) \\ repentista@hotmail.com
}

Resumen: El «pie forzado» es la más pintoresca de las variantes del repentismo, es decir, de la improvisación poética, un arte tradicional de gran arraigo en Cuba, Puerto Rico y otros países iberoamericanos. El improvisador toma un verso ajeno y tiene que improvisar una décima que termine con ese verso. Pero, ¿cómo lo hace? ¿qué técnicas usa para lograr esta proeza poética y lingüística? Hasta ahora ha sido todo un misterio por lo difícil que era entrar para el analista en la mente del improvisador. En las siguientes páginas es lo que haremos. Y no sólo para ver cómo se hace un pie forzado tradicional, sino sondeando nuevas modalidades creadas específicamente para un concurso de este género, modalidades con mayor grado de dificultad incluso.

Abstract: The pie forzado (forced foot) is the most picturesque repentismo (poetic improvisation) variant, a traditional art with deep roots in Cuba, Puerto Rico and other Latin American countries. The improviser is asked to 
take a verse of another author and to improvise a poem following the metrical structure of a «décima», ending with that verse. But how? What techniques are used to achieve this poetic and linguistic feat? So far it has been a mystery due to the difficulty that it carried for the analyst to get into the mind of the improviser. That is what we will do in the following pages. And not just to see how to do a traditional pie forzado, but testing new forms created specifically for a contest of this kind, forms that imply even greater difficulties.

Palabras clave: Décima. Improvisación poética. Repentismo. Pie forzado. Competición. Cuba.

Key Words: Décima. Poetic improvisation. Repentismo. Pie forzado. Competition. Cuba

La improvisación [...] es suficientemente importante como para exigir un análisis que se le ha negado, que no existe. Parece que el espíritu científico que nos caracteriza ha olvidado que los factores casuales encajan en las teorías físico-matemáticas de la probabilidad.

Leo Brouwer

Los aspectos de las cosas más importantes para nosotros están ocultos por su simplicidad y «cotidianidad». (Se puede no reparar en algo porque siempre se tiene ante los ojos).

Wittgenstein

El carácter performativo de la improvisación poética -interacción entre poeta y público, participación del receptor en el proceso creativo del poetaes una de sus características intrínsecas y diferenciadoras, algo que hace de este arte una de los más complejas y dinámicas manifestaciones de la poesía oral contemporánea. Y dentro de las variantes más populares de la improvisación, la conocida como el pie forzado es, sin duda, la más curiosa para el analista, la más pintoresca para el receptor y una de las más difíciles para el ejecutante.

El pie forzado, tan curioso y pintoresco como importante para entender el proceso creativo de los improvisadores de décimas, subiste en la actualidad como una variante tradicional de la improvisación de décimas, un arte que tiene en el ámbito hispánico varios siglos de existencia. Es, en definitiva, el 
pie forzado, una actualización del antiguo lexaprem griego, recurso creativo presente desde tiempos remotos en los cantares populares del medioevo europeo, en las tensones y recuestas, en el canto de ganchillo árabe y en otras manifestaciones poéticas orales. Según algunos estudiosos, el pie forzado tuvo su origen en el zéjel arábigo, y dio lugar entre otros géneros, a la glosa, que tanto se cultivó en la literatura áurea y en la poesía popular de España e Hispanoamérica durante los siglos XVIII y XIX. En tierras americanas el pie forzado y la glosa, junto a otras manifestaciones poéticas, gozaron de gran acogida tanto en la literatura escrita como en la oral, sobre todo como divertimento creativo y material de competencia. Es decir, que el pie forzado emigró a América, evolucionó y, sobre todo, sobrevivió, convirtiéndose en los últimos años en una de las más vitales y vistosas variantes de la improvisación de décimas, fundamentalmente en países como Cuba y Puerto Rico, aunque cada vez se abre camino con más fuerza en México, Chile, Panamá, Colombia, Venezuela, Argentina y otros países hispanoamericanos, manteniéndose también su cultivo en las regiones españolas de Murcia y Canarias (por cierto, únicos lugares de España en los que se conserva la décima como estrofa para el canto improvisado).

Pues bien, conocedores de la vitalidad y el crecimiento del cultivo del pie forzado entre los improvisadores de Iberoamérica, en el año 2010, aprovechando que la feria discográfica más importante de Cuba, el Cubadisco, estaba dedicada a la música campesina y al repentismo, y tenía como invitados de honor a «todos los repentistas del mundo», creamos un nuevo concurso de improvisación, un concurso sui géneris, lleno de sorpresas: el Primer Campeonato Mundial de Pies Forzados, que tendría lugar en Cuba, y cuyas expectativas se cumplieron con creces, aunque la participación foránea fue mínima por problemas ajenos al evento. Improvisar con pies forzados (es decir, improvisar décimas en las que el poeta tiene que terminar usando un verso ajeno, puesto por el público o por un jurado) es algo común, como hemos dicho, al menos en Cuba y Puerto Rico, y cada vez más en otros países. Pero improvisar con pies forzados según las variantes que nosotros creamos para este Campeonato fue toda una novedad, y una gran sorpresa para todos: concursantes, público, jurado y especialistas. De esto, precisamente, hablaremos en las próximas páginas, aunque antes de adentrarnos en el análisis de los pies forzados improvisados en este evento, debemos hacer algunos apuntes preliminares, necesarios, obligatorios, útiles. 


\section{PRELIMINARES}

1. Para el estudio exhaustivo de cualquier poema oral improvisado deben realizarse, como mínimo, cuatro análisis complementarios: a) un análisis texto-filológico (estudio léxico-semántico y literario); b) un análisis versofemológico (estudio dialógico y poético-versal); c) un análisis paralingüístico (estudio kinésino, cromético y proxémico); y d) un análisis musicológico o músico-versológico (estudio de estructuras músico-interpretativas y sus incidencias sobre el acto creativo-generativo). Estos análisis, fundidos o yuxtapuestos, serán la única fuente confiable para el estudio de la improvisación poética, sobre todo cuando falta el documento sonoro, pero también en presencia de éste.

2. La transcripción de toda poesía oral - desde el cancionero viejo al romancero, llegando a la poesía oral improvisada, la más «joven» y desconocida en estos menesteres - siempre arrastra consigo problemas inherentes al mismo fenómeno de «traducción» que implica tratar de explicar una forma expresiva valiéndose de otra (en este caso, la oralidad por la escritura). Recordemos lo que decía Sánchez Romeralo:

La cuestión de transcribir un 'texto' originariamente oral no es pues trivial ni puramente tipográfica. Es una manera de enfrentarse seriamente al texto y a la realidad poética oral en que ese texto se inserta. Lo primero será, pues, comenzar por entender esa realidad oral si queremos, en la medida en que sea posible, representarla, o representarla mejor (1989: 23).

Y en el arte específico del repentismo, hay leyes, reglas y técnicas también específicas, que constituyen su gramática y que se erigen como los únicos elementos capaces de permitir entender esa realidad oral. Un comentario y un análisis exhaustivos de cualquier controversia llevaría mucho más espacio que el que aquí empleamos, para poder apresar esa infinidad de detalles técnicos, estratégicos, lingüísticos y paralingüísticos, textuales y extratextuales, que la constituyen. Nosotros intentaremos, en el caso que nos ocupa, hacer sólo una parte de ese trabajo de sondeo: intentar rescatar los referentes contextuales que aportarán a cada décima, y por ende, al conjunto de ellas (la controversia) la consistencia necesaria, su verdadera dimensión estética, esa que conmovió a quienes fueron testigos in situ del encuentro poético, y que debe escamotearse lo menos posible a quie- 
nes sólo tendrán la oportunidad de enfrentarse a una parte de la obra: a los poemas ${ }^{l}$. Así estaremos haciendo valer una de las leyes fundamentales de la poesía improvisada: la ley de contextualidad y evitaremos que se hagan - como ha sucedido hasta ahora - análisis y valoraciones literario-textuales de poemas que llevan implícitos mucho más que las nociones de texto y de literatura: a saber, éstas dos, más recurrencias y recursos propiamente orales, aspectos contextuales y paratextuales, aspectos musicales, aspectos teatrales y hasta dramatúrgicos.

3. Los pies forzados se improvisan siempre en décimas, específicamente en décimas espinelianas de corte tradicional: diez versos octosílabos con inamovible estructura abbaaccddc, rimas consonantes y pausa obligatoria tras el cuarto verso.

\section{LA COMPETENCIA}

Normalmente, las competencias de repentismo en Cuba están organizadas en función de las controversias (diálogo amebeo, discurso dialéctico entre dos improvisadores), la variante más conocida y popular de la improvisación poética de la isla. No obstante, en todas las competencias hay también pies forzados; las controversias suelen tener una extensión de 10 ó 14 décimas (5 ó 7 cada repentista) y al final de cada controversia los poetas improvisan 1 ó 2 pies forzados cada uno. Ésas son las reglas generales y estándares de las competencias de repentismo en Cuba. Pero en este Campeonato nosotros cambiamos las reglas del juego, subvertimos el orden dándole más importancia al pie forzado, tan pintoresco, participativo, interactivo, postmoderno, aunque sin desdeñar la controversia, que la habría, claro, sólo que también con pies forzados.

En nuestro Campeonato se competía en varias categorías, algunas de ellas creadas exclusivamente para esta competencia a partir de los juegos y ejercicios que ya habíamos creado como parte de nuestra metodología para la enseñanza de la improvisación. Así, al tradicional pie forzado final que es con el que se compite normalmente en Cuba, sumamos el pie forzado inicial,

${ }^{1}$ Para ahondar en la diferencia entre los conceptos «obra» y «poema» en literatura oral, ver Paul Zumthor (1991: 83). Y para la aplicación de estos conceptos a la poesía oral improvisada (así como para la comprensión de toda la terminología técnica que hemos aplicado a los comentarios de esta controversia), remitimos al lector a Alexis Díaz-Pimienta (1998). 
los pies forzados extremos y el pie forzado móvil, el más novedoso de todos. Además, ya en la fase final de la competencia llegarían las controversias, aunque, repito, siempre con pies forzados, ora final, ora inicial, ora móvil. Hay que destacar que de todas las variantes novedosas la que más éxito tuvo entre público e improvisadores fue esta última, la del pie móvil, tanto de forma individual como en controversia, un verdadero espectáculo de creatividad, ingenio y dinamismo.

El papel del jurado en este Campeonato era evaluar, con un máximo de 10 puntos, cada décima improvisada, sumar los puntos y seleccionar a los de mejores resultados. El sistema de competencia estaba estructurado en dos primeras rondas de dos pies forzados por poeta (pie forzado final y pie forzado inicial); tras estas primeras rondas se hacía un primer corte (clasificaban sólo 8 poetas) y estos clasificados competían en otras dos rondas (pies forzados extremos y pie forzado móvil); tras estas nuevas rondas clasificaban a la siguiente fase (Semifinal), los 4 repentistas de mayor puntuación. Luego, estos cuatro se enfrentarían en la Gran Final, sacándose el orden de los contrincantes al azar, y enfrentándolos en sendas controversias, una con pie forzado final (el más tradicional) y otra con pie forzado móvil (el más novedoso). Los dos repentistas que obtuvieran mayor puntuación en esta Gran Final, se enfrentarían, entonces, en La Finalísima, el momento cumbre del Campeonato, para dirimir el ganador, el Campeón Mundial de Pies Forzados.

\section{TIPOS DE PIES FORZADOS EN COMPETENCIA}

Para que podamos entender y disfrutar en todo su esplendor la competencia, haremos una descripción detallada de cada una de estas nuevas modalidades, creados exclusivamente para el Campeonato.

\subsection{Pie forzado final}

El pie forzado final es el más tradicional y simple (sin perder la complejidad que supone improvisar una décima que termine con un verso ajeno): al poeta se le impone un verso ajeno y tiene que improvisar una décima que termine con éste. Técnicamente, como ya explicamos en Teoría de la improvisación:

El pie forzado siempre ha sido visto, por los no-repentistas, como una dificultad creativa, la prueba máxima de la capacidad improvisadora del poeta 
[...] Pero, después del análisis [...] todos coincidiremos en que el pie forzado viene a ser más bien 'una ayuda' para el poeta: el ponente le facilita al improvisador la parte más importante de la décima — el final-, por lo tanto, el poeta ya sabe a dónde ir, a dónde llegar después de los primeros versos (Díaz-Pimienta, 1998: 493).

Esto, por supuesto, no quita méritos al poeta ni «aparatosidad» y «pintoresquismo» a esta modalidad creativa, que es, como se comprobó en el Campeonato, una de las favoritas del público y una muestra clarísima de interactividad y espíritu colaborativo, es decir, de carácter transmedia ${ }^{2}$. Por eso en Teoría de la improvisación también decíamos:

La verdadera dificultad del pie forzado [final], por tanto, está en el trabajo de edición de la décima [...] El repentista debe encontrar el punto necesario de donde partir, y luego, esté donde esté ese punto, los signos necesarios para girar hasta encontrarse con el pie forzado sin que sea demasiado evidente el giro (Díaz-Pimienta, 1998: 493).

\subsection{Pie forzado inicial}

El pie forzado inicial ocurre cuando el verso ajeno ocupa el primer verso de la estrofa, no la última, y es menos habitual entre los repentistas, aunque suele usarse en un tipo de controversias que se ha ido haciendo familiar en los últimos años en Cuba, cuando fortuitamente surge un verso (a veces un simple sintagma, y entonces lo llamamos «pie forzado inicial sintagmático») que agrada y acomoda a los poetas contrincantes hasta tal punto que estos comienzan todas (o casi todas) sus décimas con el mismo verso. Lo novedoso

\footnotetext{
${ }^{2}$ Recientemente la escritora y cineasta Arancha T. Ferrero dedicó un artículo sobre transmedia al repentismo, conmovida por una controversia que vio en Internet entre Emiliano Sardiñas y yo («Plagio a los poetas muertos»; decía Ferrero en su artículo: «Ciertamente, aquí no se está contando una historia en medios distintos: no podemos hablar de transmedia tal como lo entendemos ahora. Sin embargo, sí comparte una característica con el transmedia, su carácter colaborativo. La historia no termina por decisión unilateral, sino cuando el continuo deja de fluir» (Ferrero, 2010). Entonces, una controversia lleva implícito, según este enfoque de nombre tan futurista, un fuerte «carácter colaborativo». Es cierto. Ahora bien, el hecho de que Ferrero no vea aquí una historia contada «en distintos medios», lo que legitimaría $100 \%$ el carácter trasnsmedia de la controversia, se debe a que ella no considera medios distintos lo que nosotros sí (la voz, el gesto, el texto), ni siquiera los considera «medios». Aunque desde nuestro punto de vista, sí es transmedia una controversia, ¡transmedísima!, si tomamos en cuenta lo anteriormente dicho. Para ampliar sobre el término transmedia, véase: http://noticiastransmedia.com/index.php/2010/06/09/transmedia-trans-to-what/.
} 
aquí, entonces, es el carácter impositivo de ese verso inicial, el forzamiento en sí mismo.

Técnicamente hablando, el pie forzado inicial es, en nuestro criterio, un poco más difícil que el final, ya que el poeta se lanza al vacío, sin red, es decir, sin tener preparados los versos finales de la décima, el hacia dónde, el apeo, el hachazo. Esta sensación de improvisación «cuesta arriba» (yendo cuesta abajo) es muy significativa, porque cambia todo el esquema creativo del poeta. El improvisador, con un pie inicial, sabe de dónde sale pero no a dónde llegará, y el receptor está en la misma situación, por lo tanto, las expectativas son mayores y la emoción es también mayor cuando se logra llegar bien a puerto (a buen puerto). Por supuesto, los repentistas más dotados y técnicos lograrán hacer el pie forzado inicial usando, a la inversa, la misma técnica que con un pie forzado final; es decir, si en para el pie final los pasos son: 1) preparar el bajante (verso 9, para completar el último hexadecasílabo); 2) seleccionar los vocablos primarios de los versos 9 y 10 (palabras X: sustantivos, adjetivos, verbos y adverbios); 3) saltar al principio de la décima y comenzarla introduciendo (vv. 1 y 2) palabras X1, X2, X3, etc. (términos que pertenezcan al mismo campo semántico de las palabras $\mathrm{X}$ antes seleccionadas, o a su familia de palabras); y 4) ir editando, moviendo y entretejiendo las ideas desde el verso 1 hasta el 10 (el pie); si todo esto es lo que hace un repentista técnicamente bien dotado para contestar un pie forzado final, lo mismo, pero a la inversa deberá hacer con un pie inicial; es decir (por pasos):

1) preparar el equivalente al bajante (en este caso, el verso 2, para completar el primer hexadecasílabo);

2) seleccionar los vocablos primarios de los versos 1 y 2 (palabras $X:$ sustantivos, adjetivos, verbos y adverbios);

3) saltar al final de la décima y preparar los vv. 9 y 10 introduciendo en ellos palabras $\mathrm{X} 1, \mathrm{X} 2, \mathrm{X} 3$, etc. (términos que pertenezcan al mismo campo semántico de las palabras $\mathrm{X}$ antes seleccionadas, o que pertenezcan a su familia de palabras);

4) ir editando, moviendo y entretejiendo las ideas desde el verso 1 (el pie forzado) hasta el verso 10 (el final), o, para ser más exactos, desde el primer hexadecasílabo (verso A) hasta el quinto (verso C). 


\subsection{Pies forzados extremos}

En esta modalidad el poeta tiene que improvisar una décima con dos pies forzados, el primero como pie inicial (verso 1) y el segundo como pie final (verso 2).

La décima improvisada con pies forzados extremos es también una invención nuestra, a partir de los ejercicios creados para el trabajo formativometodológico en las escuelas de repentismo. Es éste un ejercicio en el que, fundamentalmente, se ejercita la edición, el ensamblaje de la décima, y sirve para reforzar el trabajo de coherencia textual. Técnicamente, ésta es, sin duda, la modalidad más compleja y difícil de la competencia, donde el azar puede jugar en contra de la creatividad del poeta. Aquí el improvisador está sujeto más a las habilidades que a la creatividad, está más en función del espectáculo que de la poeticidad ${ }^{3}$. El trabajo de edición es fundamental para garantizar la coherencia de una estrofa improvisada, y, por lo tanto, su eficacia. Pero convengamos y confirmemos, nosotros también, que amén de las habilidades del poeta, el azar puede ser un escollo enorme en este juego-ejercicio. No es lo mismo intentar unir en una misma décima dos ideas tan «cercanas» como «a dónde van los difuntos» (de José Martí) y «descansan bajo la tierra» (de Antonio Machado), que dos ideas tan «distantes» como «Al negro de negra piel» (de Nicolás Guillén) y «te morderán los zapatos» (de Federico Garcia Lorca). Podría darse incluso el caso -que no se dio por puro azar- de que hubiera una clara incongruencia entre los tiempos verbales o las personas gramaticales de un verso y otro, lo que obligaría al repentista a hacer malabares sintácticos, más que semánticos y más que lingüísticos. En fin, la décima con pies forzados extremos fue una de las modalidades más pintorescas y mejor recibidas por el público, no así por todos los poetas.

\subsection{Pie forzado móvil}

En esta modalidad se selecciona un pie forzado de la lista general y una vez seleccionado se tira el «dado forzado» (o «dado poético» o «dado forzado»), y el número que salga identifica el número del verso en la décima donde el poeta debe poner el pie forzado móvil. Tenemos que aclarar aquí

${ }^{3}$ El repentista matancero Jesús «Tuto» García llegó a decir incluso que este campeonato era una «máquina de destruir poetas», destacando el carácter y el interés meramente poetizador de los repentistas cubanos, frente a otros intereses (el espectáculo, el ingenio, la pirotecnia verbal). 
que el dado poético, no es un dado común, sino un dado creado exclusivamente para este ejercicio y esta competencia, un dado en cuyos lados los números que aparecen no fueron seleccionados al azar, sino tomando en cuanta aquellos versos de la décima en los que un verso ajeno puede «hacer menos daño», donde el forzamiento sintáctico puede ser menos violento. Así, por ejemplo, se excluyeron los números 3 y 7 , versos con función esencialmente hilativa, de enlace, versos-puente, versos para «abrir» y «llegar-buscar» la idea principal, definitiva.

Técnicamente hablando, el pie forzado móvil es complejo, pero no difícil, dependiendo, claro, del número que salga en el dado poético. Los grados de dificultad varían mucho entre que el verso caiga en el numero 1 o 10, a que caiga en el 5 o el 6. Tampoco es muy difícil en el verso 4, final de la primera redondilla. Aquí vale la pena contar que en todo el Campeonato hubo sólo dos incidencias (ambas en la primera jornada, en Limonar, Matanzas). La primera con el pinareño Oniesis Gil, quien en la ronda del pie forzado inicial dejó el verso impuesto para el final, y comenzó con otro, pero fue advertido a tiempo y rectificó; y la segunda con el habanero José Enrique $\mathrm{Paz}$, quien tenía que colocar su verso en un número determinado y lo puso en otro. Éste es otro de los aspectos técnicos y extrapoéticos que inciden en el improvisador: ya no solo debe concentrarse y preocuparse de la factura textual y poética de su décima; ahora también debe llevar la cuenta de los versos para colocar el pie allí donde debe. Esto parece poco complejo, pero sí lo es, y mucho, si tenemos en cuenta que los poetas repentistas, mucho más a este nivel, jamás piensan en la estructura de la décima, algo que ya tienen tan aprendido y aprehendido como el resto de los hablantes las estructuras gramaticales del habla común. Ningún hablante normal del español piensa $a$ priori que un adjetivo debe ponerse junto al sustantivo, simplemente lo pone. Se convierte, entonces, el lugar donde poner el pie, en una dificultad añadida a la ya compleja improvisación de décimas.

\subsection{Controversia con pie forzado móvil}

Ésta, como dijimos antes, fue una de las grandes sorpresas del evento, un tipo de controversia que, creemos, llegó para quedarse. Se selecciona un pie forzado «móvil» de la lista general y una vez escogido el pie forzado, cada poeta debe improvisar una décima usando el pie en un verso distinto, en grado descendiente, del 1 al 10. Es decir, el poeta A utiliza el pie forzado en el verso 1; el poeta $\mathrm{B}$, en el verso 2; el A, en el 3; el B en el 4; el A en el 5; el B, en el 6; el A en el 7; el B en el 8; el A en el 9; y el B en el 10. 
El esquema de la controversia quedaría así:

Poeta A.........pie forzado.........verso 1
Poeta B .......pie forzado.........verso 2
Poeta A .......pie forzado.........verso 3
Poeta B........pie forzado.........verso 4
Poeta A .......pie forzado.........verso 5
Poeta B .......pie forzado.........verso 6
Poeta A .......pie forzado.........verso 7
Poeta B .......pie forzado.........verso 8
Poeta A .......pie forzado.........verso 9
Poeta B .......pie forzado..........verso 10

Al final, queda una controversia de 5 décimas cada uno, con el mismo pie forzado, que se mueve, que se desplaza y aparece cada vez en un momento-lugar distinto de la estrofa, del verso 1 al 10.

\section{4. ¿DE DÓNDE SALIERON LOS PIES FORZADOS?}

Para este evento, tomando en cuenta el número de participantes, seleccionamos cientos de versos de decenas de poetas de la lengua española, de todos los tiempos, lugares y estilos, de manera que el abanico de posibilidades poéticas fuera amplio. Tuvimos a la vez el cuidado de escoger, teniendo en cuenta las características de la décima improvisada, cuáles eran más idóneos para cada categoría. Así llegamos al primer día del evento con un «morral poético» lleno de versos firmados por grandes poetas, en total, 499 versos para pies forzados finales, 199 para pies forzados iniciales y 162 para pies forzados móviles (los pies forzados extremos se escogían entre los finales y los iniciales). Esta extensa y variopinta selección de versos de la obra de tantos grandes poetas, desde los clásicos del Siglo de Oro español hasta poetas cubanos y latinoamericanos contemporáneos, propiciaba, $a$ priori, un intenso e interesante diálogo entre oralidad y escritura. Cada uno de estos poetas, a través de sus versos, fue re-visitado por los repentistas y actualizado in performance en un ejercicio de lesa post-modernidad, una mezcla sublime de tradición y vanguardia. Nada hay tan postmoderno como el pie forzado. Los improvisadores cubanos, puertorriqueños, canarios y 
murcianos (por poner 4 ejemplos cercanos) llevan décadas, incluso siglos, poniendo en práctica lo que ahora, en el súmmum de la postmodernidad, parecen haber descubierto los match de impro (improvisación teatral), las peleas de gallo (improvisación rapera), el free style, los slam poetry, etc.

Veamos algunos ejemplos de la selección de pies forzados:

Pies forzados finales:

¡Yo estoy triste y tú estás muerta! (JUAN CLEMENTE ZENEA)

A cada paso que daba (ALFONSO REYES)

A la luna, quieta y sola (MIGUEL DE UNAMUNO)

Como si fueran ajenas. (J. L. BORGES)

Como una grandiosa espina (MIGUEL HERNÁNDEZ)

Con el sudor de su cara (LOPE DE VEGA)

Descansan bajo la tierra. (ANTONIO MACHADO)

Desde dentro están llamando (JUAN RAMÓN JIMÉNEZ)

El peso de mis miserias (SOR JUANA INÉS DE LA CRUZ)

Que su limpieza exagere (FRANCISCO DE QUEVEDO)

Te morderán los zapatos. (FEDERICO GARCÍA LORCA)

Teje una doble corona (JOSÉ LEZAMA LIMA)

Pies forzados iniciales:

A dónde van los difuntos (JOSÉ MARTÍ)

A veces con loco intento (RAMÓN DE CAMPOAMOR)

Al llegar la hora esperada (LEOPOLDO LUGONES)

Al negro de negra piel (NICOLÁS GUILLÉN)

Cantando viejas baladas (MIGUEL DE UNAMUNO)

Curiosísima señora (CALDERÓN DE LA BARCA)

En la blancura del llano (RAMÓN LÓPEZ VELARDE)

La tierra se va cansando (DULCE MARÍA LOYNÁS)

No soy dueño de mí mismo (SALVADOR RUEDA) 
Pies forzados móviles:

Yo he visto muchos cantores (JOSÉ HERNÁNDEZ)

Yo no sé por qué motivo (JUAN CLEMENTE ZENEA)

Yo que todo lo he perdido (GABRIELA MISTRAL)

Una canción marinera (EVARISTO RIBERA)

Que triste tiene que ser (ADOLFO MARTÍ)

Bajo el cielo y sobre el mar (RUBÉN DARÍO)

Con el semblante marchito (G. G. DE AVELLANEDA)

De maneras diferentes (JULIÁN DEL CASAL)

De mi existencia pasada (JUAN CLEMENTE ZENEA)

Del tropical aguacero (JOSÉ GAUTIER)

La lista de autores de la poesía escrita que «participaron» en esta fiesta poética oral fue amplísima. A los ya citados sumemos, por ejemplo, a Gertrudis Gómez de Avellaneda, Eliseo Diego, Luis Cernuda, Julio Herrera y Reissig, Dámaso Alonso, Nicanor Parra, Gabriela Mistral, y muchos más. Pero también hubo poetas orales, como Silvio Rodríguez y Pablo Milanés, e improvisadores como Pablo León, Ángel Valiente, Bernardo Cárdenas, Chanito Isidrón, Chanchito Pereira, Manolito García o el mismísimo Indio Naborí.

\section{ALGUNOS EJEMPLOS DE IMPROVISACIONES A LO LARGO DEL CAMPEONATO}

Con todo esto, el espectáculo estaba asegurado y había para satisfacer todos los gustos. Veamos entonces, revivamos ahora, algunos de los mejores momentos de este campeonato.

El siguiente «pie forzado inicial» es un verso del español Calderón de la Barca y fue resuelto en la fase clasificatoria, en Güines, por el repentista Leandro Camargo: «Yo soy un hombre de tan...». Suena la música y responde el poeta utilizando un tiempo previo de sólo 27 segundos:

Yo soy un hombre de tan

inusitado destino 
que cuando ven el camino

los zapatos se me van.

De mi destino sabrán

las ancianas carreteras,

la nieve de mis ojeras

lo sensible del momento

los recovecos del viento

y el polvo de las aceras.

El poeta ha usado un tiempo de enunciación de 30 segundos (desde que canta el primer verso hasta que canta el décimo), es decir, que tardó en total (tiempo previo + tiempo de enunciación) 57 segundos en improvisar esta excelente décima, con un alto nivel de eficacia e innegables hallazgos poéticos. Pocos repentistas cubanos podrían haber resuelto este pie forzado inicial, tan abierto y con ese incómodo encabalgamiento, con tanta facilidad y desparpajo como el joven Leandro Camargo, quien, por su formación académico-literaria, está más cerca de este tipo de recursos. Cabe destacar también el toque filosofante de la décima -típico también de la poética camarguina-, y la lograda enumeración versal a partir del verso quinto, lo que le imprimió velocidad a la estrofa. Hay que destacar -obligatorio para tener una «visión» y una decodificación total del poema improvisado- el buen uso de recursos kinésicos -movimientos corporales, lenguaje gestual-, que complementan (y completan) el discurso poético oral improvisado.

Veamos un mínimo cuadro de lenguaje corporal en esta décima:

- Movimiento ilustrativo de los brazos en el verso 4 (camino + zapatos que se van).

- Ídem. en el v. 6 (ancianas carreteras).

- Gesto ilustrativo y enfático en el v. 7 («ojeras» = se toca la parte inferior del ojo derecho).

- Gesto ilustrativo y enfático en el v. 8 («momento»= típico gesto con la mano semicerrada punteando hacia abajo = «aquí y ahora»).

- Gesto ilustrativo y enfático en el v. 9 («viento»= el brazo despreocupado señala el vacío).

- Gesto ilustrativo y enfático en el v. 10 (aceras = ambas manos señalando hacia el suelo y adelante). 
También en la fase clasificatoria, en Güines, improvisó esta décima Luis Quintana con el pie forzado inicial, «Encontrarás poesía», un verso de José Asunción Silva:

\section{Encontrarás poesía}

en los besos que te he dado

y verás que en mi pasado

no existió la hipocresía.

A lengua de maestría

tus curvas voy a lamer

hasta que dejes caer

tímidas gotas de orgasmo

y eches en cofres de espasmo

perlas de goce y placer.

He aquí una décima filo-erótica de lograda belleza y plasticidad. El poeta toma el camino de la décima amorosa (esa mujer/sujeto omitido, ese «tú» femenino que tanto se usa para solucionar décimas anecdóticas y argumentales) y lo consigue diríamos que incluso con cierta suavidad, explícita hasta en la tonada y en el tono del canto. Después de una primera redondilla limpiamente expositiva, sin grandes pretensiones, comienza el puente ya con intencionada subida de tono, cambiando los suaves términos «poesía» y «besos» por los más carnales «lengua» $\mathrm{y}$ «lamer». Aclarado el rumbo del discurso, queda destacar el uso tan personal que da Luis Quintana a la preposición «a» en muchas de sus décimas, haciéndola sustituta de la preposición «con»: «a lengua de» en lugar de «con lengua de»; este tipo de uso es bastante común en el habla funcional del campesinado cubano, pero lo destacamos por lo reiterado de su presencia en la obra de Quintana, unas veces con mayor felicidad que otras. Y por último, destacamos la contundencia y limpieza del lenguaje erótico en la última redondilla donde el poeta entrecruza con verdadero arte y buen tino piezas lingüísticas de gran connotación y eficacia como son «caer», «gotas», «orgasmo», «cofres», «placer», «perlas, «goce», «espasmo»; esta sucesión de términos que disimulan y a la vez exponen cierta sicalipsis está medida y distribuida con tal exactitud que el erotismo es conseguido hasta el aplauso. Quizá contribuye a ello el adjetivo «tímidas» que le regala a las «gotas» y el hecho poetizador de convertir los espasmos en cofres y las gotas de placer en perlas. Todo esto usando un tiem- 
po previo de 95 ss. y un tiempo de enunciación de 27; en total, 122 segundos. ( 2 minutos y 2 ss.), un registro bastante alto considerando el estilo y la poética típica de Quintana. Además, en esta décima Quintana utiliza un lenguaje gestual parco, acorde con el tono lánguido de su interpretación (como si susurrara la décima en lugar de cantarla, como si nos advirtiera a los oyentes que su discurso es «íntimo», resaltando el voyerismo auditivo de nuestra recepción). Desde el punto de vista kinésico, lo más destacables son los puntillosos y «goteantes» gestos de la mano izquierda en los vv. 7, 8 y 9.

También el pinareño Oniesis Gil improvisó esa tarde con pie forzado inicial, sobre un verso de Nicolás Guillén:

\section{Hay gentes que no me quieren}

y ni mi tamaño miden

y gentes que no me piden

$y$ hay otros que me prefieren.

Esos que por mi se mиeren

reconocen mi apellido

más para el que tiene herido

el dique de la memoria

soy un fragmento de historia

ahogándose en el olvido.

Ésta es una décima lastrada por un pie forzado que aporta poco, que ayuda poco al nivel y al gusto de ensoñación de los repentistas cubanos; más bien invita al discurso quejumbroso y de tintes revanchista, pero en abstracto, como el que intenta (y logra) el poeta pinareño. La enumeración anafórica de la primera redondilla no es todo lo feliz que podría, hubiera sido mejor sustituir la segunda «y» por el también anafórico «hay». Tal vez los mejores hallazgos, los más lúcidos, son ese «dique herido» de la memoria, y ese «fragmento de historia» que «se ahoga» (es decir, el olvido como mar donde el poeta puede llegar a ser una insignificancia).

Cuadro kinésico y cronémico:

1. Tiempo previo: 56 ss.

2. Tiempo de enunciación: 44 ss. 
3. Total: 100 ss. (1 min. y 40 ss.).

4. Parco lenguaje gestual, casi nulo; apoyo total en la intensidad de la mirada y en los resortes paraverbales (tono lánguido, distante, tranquilo, seguro).

Y por último, del veterano Rafael García escogemos la siguiente décima con pie forzado móvil, una frase que, obligado por el «dado poético», tuvo que colocar en el verso 5 de la décima: «Al ofrecerte una rosa». Y dijo García:

Mujer, a qué mariposa
puedo pedirle el color
para saber si tu amor
en mi corazón se posa.

Al ofrecerte una rosa

te estoy brindando mi vida

porque una boca encendida

por un beso despintada

no se sabe si es la entrada

del amor o la salida.

He aquí un ejemplo de décima improvisada con varios soportes comunicativos (el famoso transmedia): el textual, el interpretativo-oral y el gestual, de manera que el receptor recibe la obra completa en varios soporte-lenguajes (medios): como si oyera con subtitulaje (¿los gestos son a la improvisación lo que el sub-titulaje al cine?; ahí dejo la pregunta. Sigamos). Esta décima es una de las mejores que se improvisaron en la sesión competitiva de Güines, el día 14 de mayo. Grande desde el tono interrogativo del inicio, hasta esa entrada deíctica con vocativo directo (no ese «tú» femenino que funge casi siempre como sujeto omitido por comodidad métrica, sino la presencial o evocada «mujer»); pero también hay otros hallazgos: la misma pregunta en sí, o esa mariposa dueña del color (¿rojo?) que él poeta quiere pedir-tener para saber si su amor le pertenece («se posa»), un hermosísimo hallazgo, redondez de la búsqueda, cuadratura del círculo. Luego, el puente es perfecto, con pie forzado incluido, y el desenlace no puede ser más exacto y fluido, en parte por el buen empleo del codo sintáctico «porque», pero, sobre todo, por esa boca «encendida» y a la vez «despintada» (lo curioso es que está des- 
pintada «por un beso»; ¿y encendida por qué?), para rematar con la exactitud de los maestros, jugando a las puertas equívocas y a ciertos espejismos típicos de la pasión amorosa.

Cuadro kinésico y cronémico:

1. Tiempo previo: 34 ss.

2. Tiempo enunciación: 1 min. y 11 ss.

3. Total: 75 ss (1 min. y 15 ss.).

Lenguaje corporal:

1. Apoyo gestual ultra-enfático en el verso 4 («corazón»= repetidos golpes sobre el pecho con la mano abierta.

2. Gesto enfático en los versos 5 y 6 (ofrecerte mi vida).

3. Gestos enfáticos y redundantes en los versos 7 y 8 («boca encendida», «[boca] despintada»= el poeta se toca los labios).

4. Gestos enfáticos y redundantes en los versos 9 y 19 («entrada» y «salida»).

5. Apoyatura total en los resortes paralingüísticos (tono alto, timbre también enfático, cierta «agresividad afectiva» en la mirada, lo que denota cercanía y seguridad).

\section{LA FINALÍSIMA: CONTROVERSIA ENTRE LEANDRO CAMARGO Y LUIS PAZ «PAPILLO», CON PIE FORZADO FINAL A PARTIR DEL VERSO «HAMBRIENTO Y SIN QUÉ COMER», DE MIGUEL HERNÁNDEZ.}

Tendremos que comenzar diciendo que tras tres jornadas de ardua competición, con décimas improvisadas que honrarían cualquier antología del género, los repentistas clasificados fueron los siguientes: Leandro Camargo (Cuba), Omar Santiago (Puerto Rico), Yordán Quintero (Cuba) y Luis Paz «Papillo» (Cuba), y de estos cuatro improvisadores, los finalistas fueron: Leandro Camargo y Luis Paz «Papillo». Estos dos finalistas tuvieron, entonces, que enfrentarse en sendas controversias con pie forzado: una con pie forzado final y otra con pie forzado móvil. Por problemas de tiempo y espacio, analizaremos aquí sólo una de ellas, la controversia con pie forzado final, 
desarrollada con el verso del poeta español Miguel Hernández «hambriento y sin qué comer».

Hay muchas maneras de acometer una controversia con pie forzado final, tal vez tantas como improvisadores. Todo depende del estilo de cada poeta y de los grados de dificultad del pie. En este caso, Leandro Camargo y Luis Paz «Papillo» son dos repentistas de estilos muy distintos, aunque perfectamente «ensamblables»; Carmargo, más conceptual y parabólico, aportador de una mirada y un lenguaje frescos en el panorama actual del repentismo cubano; Papillo, un repentista más visceral y telúrico, más ruralista y efectista; se enfrentaban, además, dos imágenes socialmente diferenciadas; Camargo representaba al joven desconocido, valor en alza, pero, sobre todo, joven; y Papillo al repentista consagrado por los medios y el prestigio tras una carrera cimentada. Estos detalles pueden a priori y durante la controversia haber influido en el público (hacia un lado, o hacia otro), y en el jurado (que en definitiva, no deja de ser público), pero no tendrá peso alguno en nuestro análisis de la controversia, convencidos como estamos de que el nivel poético y la efectividad alcanzados por ambos en este campeonato tiene menos que ver con sus nombres, edades y prevalencencia social, que con el nivel creativo que desarrollaron esa noche concreta.

Comienza el diálogo Luis Paz «Papillo»:

\section{Papillo:}

Me gusta la madrugada

llena de estrellas fugaces

sílabas para las frases

de una canción olvidada.

Ver la luz agazapada

como una estatua de ayer

pues cuando el amanecer

despierta sin arrebol

yo pienso que nace el sol

hambriento y sin qué comer.

Una feliz primera redondilla y una última redondilla algo confusa. Los mejores momentos de esta décima son esas estrellas fugaces convertidas 
en sílabas de una canción olvidada (¿la noche?). La noche como canción olvidada es un hallazgo hermoso que alivia bastante el fácil recurso que emplea el poeta en el primer verso, ese «me gusta» que tanto se ha usado como pie sintagmático inicial en nuestras controversias. Luego es un misterio hermoso esa luz «agazapada» como una estatua, pero no como una estatua cualquiera, sino como una estatua «de ayer», «antigua», «pasada», de «ya no»; es hermosísima la imagen plástica de la luz «agazapada», «escondida» y a la vez quieta, inmóvil («estatua»). Y cuando hablé al principio de una última redondilla un poco «confusa» me refería concretamente a los versos 7 y 8 (¡ojo!, los más difíciles de cualquier décima improvisada), porque la idea queda clara en su conjunto, pero es algo escurridiza: ¿el amanecer sin arrebol provoca que el sol esté hambriento? ¿y sin qué comer? Lo único que parece poner algo de orden en este desconcierto es ese «yo creo que», matizador y salvador al principio del noveno verso.

\section{Camargo:}

Mujer, te quiero desnuda

como los buenos tesoros

que ya me hincan en los poros

las agujas de la duda.

Te estás haciendo la muda

pero responde mujer

porque desde que el placer

en la sangre se me inflama

me tienes junto a la cama

hambriento y sin qué comer.

Ésta es una décima limpia en su estructuración y en su lenguaje. El vocativo deíctico «mujer» nos ubica rápidamente en un diálogo (el poeta y una mujer, presente o evocada). Luego, destacamos esa duda «que hinca», que tiene «agujas», y ese puente en el que se retoma el vocativo «mujer» imprimiéndole a la décima, de un solo golpe, coherencia, rapidez y énfasis; y luego un remate perfecto, con movimientos ágiles y perfectas imbricaciones léxicas: «placer», «sangre», «inflama» «cama», «hambriento», «sin comer», logrando el poeta una metáfora continuada que constituye alegoría, porque todo el tiempo habla de sexo sin mencionarlo, ha hecho un traslado de sig- 
nificados, un viaje del lenguaje directo al figurado, del hambre real al hambre metafórica, de la alimentación prosaica, al amor y al sexo.

\author{
3. Papillo \\ Yo, que en el campo nací \\ alargando el recorrido \\ soy un sinsonte sin nido \\ que anda suelto por ahí. \\ Llevo por dentro de mí \\ un padre sin comprender \\ y así me quiero volver \\ alpiste en la gajazón \\ cuando me encuentro un pichón \\ hambriento y sin qué comer.
}

Papillo se sumerge aquí en el discurso ruralista típico de una gran zona del repentismo cubano (cucalambeísmo ${ }^{4}$ ) y se refugia en imágenes que no por tópicas dejan de ser funcionales: el poeta sinsonte. Luego, los vínculos padre-hijo que vislumbramos en el puente se resuelven en la última redondilla, concretamente en los dos versos finales, cuando el poeta aclara que él quiere ser «alpiste» en la gajazón para ayudar-alimentar al «pichón» (léase, niño, joven, principiante, aprendiz de poeta) que se encuentre. Los saltos semánticos en esta décima son un poco abruptos y por eso nos deja cierta sensación de mareo, de desasosiego. El poeta construye una alegoría llamándose a sí mismo «sinsonte sin nido» que gracias a su padre alargó «su recorrido» lejos del campo y que quiere (en un futuro) hacerse «alimento de» (ayudar a) otros pichones de sinsonte. La idea nos vuelve a parecer algo confusa, sobre todo en los versos 6,7 y 8 , como si se trabara un poco y sin la contundencia necesaria para el remate perfecto y el refuerzo de la idea global de la estrofa.

4 Juan Cristóbal Nápoles Fajardo, el Cucalambé, fue el decimista más importante de Cuba en el siglo XIX, poeta que cubanizó la décima con sus cantos bucólicos y sus loas poéticas al paisaje de la isla. El Cucalambé creó escuela, marcó estilo, y llenó el decimismo cubano de epígonos, tanto en la literatura escrita como en la oral improvisada. El cucalambeísmo es, aún hoy, un movimiento poético de fuerte arraigo entre los repentistas. 


\section{Camargo:}

Pobre el que tiene dinero

para echar en su alcancía

pero que deja vacía

la mano del limosnero.

A ese más pobre lo quiero

que el pobre que pueda haber.

Pues quiero ver qué va a hacer

ese día que se halle

vagabundo por la calle

\section{hambriento y sin qué comer.}

Otra excelente décima de evidentes tintes calderonianos, con tan ejemplar estructuración como ejecución, por su ritmo y su fuerza expositiva. Es realmente una fábula. $\mathrm{O}$ un epigrama fabulado. Camargo juega (ya en la segunda décima están más definidas las líneas estilísticas) a ser poeta abridor y al uso de décimas «independientes», casos concretos, individuales. Como estampas, cuadros, galería de personajes. Primero fue una mujer. Ahora un rico avaro. Pero también permuta de punto de vista: primero la deixis y el vocativo dialógico; ahora ese impersonal y distante «pobre del».

\section{Papillo:}

Mi padre siempre decía

que el trabajo es lo mejor

hay monedas de sudor

que no caben en el día.

Búscale a la sitiería

algún sueño que tañer.

No dejes de comprender

el fruto de tus ideas

para que nunca te veas

hambriento y sin qué comer. 
Ahora Papillo retoma al personaje del padre, que ya había aparecido en su segunda décima, dando la sensación de que va a elaborar él también su personal galería de personajes, aunque repita. Pero es sólo una primera impresión. En realidad, Papillo está aplicando la técnica de la riposta, respondiendo a la primera redondilla de la décima anterior de Leandro (este hablaba de «dinero» y «alcancía»; él habla de monedas) e incorporando el personaje del padre porque esto da sensación de continuidad a su discurso, que empieza a entretejerse con el otro: un claro síntoma controversial. Y culmina una décima efectiva aunque de pocos hallazgos, en la que dice lo que quiere para responder-ripostar: el sudor es la mejor moneda, no dejes de trabajar («de comprender / el fruto de tus ideas») para que no termines como dice el pie forzado. Lo mejor de esta décima es el regreso del padre como personaje $y$, a nivel poético, ese «sueño tañible» en la sitiería. ¿Tañer un sueño en el medio del monte? Bucólico, ¿no?; pues más bucólico y poético es que te pidan que lo busques.

\section{Camargo:}

Desde que me di a estudiar

a aquel que cayó en la sierra

con los pobres de la tierra

quiero yo mi suerte echar.

Todo me puedo ganar

pero siempre voy a ser

consciente con el deber

de la gente que me cuida

aunque me quede en la vida

\section{hambriento y sin qué comer.}

Carmargo sigue incrementando su galería personal. Ahora se atreve con Martí e incluso lo cita textualmente (vv. 3 y 4) en un ejercicio de intertextualidad poco frecuente en el repentismo cubano. Amén del tono moralizante, logra una décima bastante limpia, aunque desde el punto de vista sintáctico se hace un lío en los versos 6, 7 y 8 . Tal vez empujado por la velocidad enunciativa y por la propia sintaxis escogida (suave encabalgamiento entre los versos 6 y 7, pero con una idea continua y ternaria -bastante inusual- entre los vv. 6, 7 y 8) el poeta se extravía y expresa de la forma en que ya han 
leído unos versos que pudieron (debieron) ser así: «pero siempre voy a ser / consciente de mi deber / con la gente que me cuida». De todos modos, aquí todos, jurado, público, el propio Camargo, yo mismo entre el público, echamos mano a la zhumthoriana «comprensión residual» y decodificamos perfectamente lo que dijo, es decir, lo que quiso decir. Gajes de la oralidad, a veces incomprendidos (no incomprensibles) desde la escritura.

\section{Papillo:}

Mi madre, rosa en las manos,

me aconseja en los postigos:

comparte con tus amigos

como si fueran hermanos.

Hállale a los meridianos

la flor de otro amanecer

que tener mucho, tener

todo y nada regalar,

eso es lo mismo que estar

\section{hambriento y sin qué comer.}

Ahora Papillo se acoge al tono moralizante de Camargo e insiste en su propia galería (más personal imposible) incluyendo a su madre. En la primera redondilla destacaremos ese «en los postigos» como un inexcusable calzador semántico (y rimal), pero también esa fina y encubierta metáfora (fina y anfibológica) de la madre como «rosa en las manos». Aquí «los postigos» son un sinónimo aproximativo y sustitutivo de «las puertas» (en realidad, de «la puerta»: el plural surge obligado por la rima «amigos»); el poeta quiere decir que su madre le aconseja desde «la puerta», la madre, $\dot{i}$ «rosa en las manos»?, ¿el poeta se refiere a su madre, como una rosa en sus manos de hijo; o es una evocación plástica de una madre con una rosa en las manos, aconsejando al hijo? He aquí lo anfibológico, inevitable a veces en la oralidad, tan inevitable como inocuo: cualquiera de las dos lecturas dota a estos versos de una fuerza poética diferente, pero fuerza al fin y al cabo. De ahí su eficacia. Pero lo mejor de esta décima comienza en el puente (vv. 5 y 6 ) y se acrecienta en la redondilla final (vv. 7-10). Al sencillo pero eficaz hallazgo del amanecer como flor, hay que sumarle la velocidad, el ritmo y el atrevimiento con que Papillo acomete el desenlace, con un marcado énfasis (ese 
«tener» repetido) y un perfecto y difícil encabalgamiento (tener mucho, tener / todo) para cerrar con elegancia, devolviendo el tono moralizante de la décima precedente.

\section{Camargo:}

Mi padre, que no envejece,

al ver mis manos callosas,

me dijo «dale las cosas

a aquel que se las merece».

En el fondo, me parece,

el secreto está en crecer.

$Y$ como tengo el placer

de estar feliz para dar

nunca me voy a quedar

\section{hambriento y sin qué comer.}

Leandro incorpora esta vez a su padre (él también) como personaje de su galería y emplea el mismo recurso de Papillo (el personaje poemático, el padre, habla, aconseja, dice). He aquí otra fábula improvisada, otro epigrama con diálogos intercalados, y otra vez un discurso moralizante y algo didactista. Su padre («que no envejece», el mejor sintagma de la redondilla) es el que habla a través de sus versos. Ésta es otra décima limpia desde el punto de vista sintáctico y semántico. Impecable su estructura con un codo sintáctico idóneo, lo que garantiza la fluidez de la estrofa. Si algo hay que destacar en esta décima es la inteligente reutilización del signo «padre», tomado de las décimas anteriores de Papillo («padre», «madre») lo que garantiza ese profundo sentido de continuidad dialógica. La estructura y secuenciación léxica de la décima es perfecta, asegurándose la sensación de plenitud expositiva: en la primera redondilla, «padre» «dijo» «dale»; en el puente, un «me parece» que, por una parte, matiza la información y un «secreto» que provoca cierta cercanía paterno-filial, subliminalmente entroncable con la idea inicial de la primera redondilla; y en la segunda redondilla, «placer», «estar feliz»y «dar» redondean la impresión receptora de que en toda la décima se ha estado hablando de lo mismo: coherencia y plenitud expositiva. 


\section{Papillo:}

Yo, que soy un soñador

de guateque y canturía,

con diez hilachas de guía

salgo a inventarme una flor.

Me cabecea el rumor

de lo que no sé entender

pero así salgo a tejer

la última primavera

para que el verso no muera

hambriento y sin qué comer.

En esta décima lo más destacable es la presencia del simbólico número diez en el tercer verso («diez hilachas»), con la que el poeta asume uno de los elementos retóricos más comunes del repentismo cubano, la referencia numérica a la décima. «Con diez hilachas de guía», dice el poeta, para que oigamos «con una décima de guía», hilachas que entroncan semánticamente con ese «tejer» del verso 7, por lo tanto, el poeta, «soñador», se inventa una flor «tejible», guiado por la décima, y aunque a veces no sepa entender (v. 6) «teje la primavera» con ella. No fue esta una de las décimas más logradas por Papillo, pero sí fue efectiva, como todas las otras.

10. Camargo:

Creo que nunca estará

sólo aquel que lleva luz.

y que carga con su cruz

a donde quiera que va.

No me importa el que te da

la espalda para volver.

Date por dentro a crecer

y lúchalo cuando puedas

que si es por mí no te quedas

hambriento y sin qué comer. 
Aquí Camargo vuelve al tono dialógico directo, a la segunda persona apelativa y referente a su «compañero de combate». No obstante, tampoco logra un discurso claro, bien entretejido. En la primera redondilla (esta sí, redonda en sí misma) logra una introducción clara, referida a una abstracta tercera persona («el que lleva luz», «el que carga» con su cruz). Sin embargo, ya en el quinto verso hace un giro brusco -y poco justificado- hacia la segunda persona, hacia su interlocutor (el pronombre «te» en el verso 5) y se mantiene hasta el final en este tono de diálogo directo, dejándonos incluso un «lúchalo» sin saber muy bien qué es lo que tiene el otro que luchar. Todos estos cabos sueltos resienten la décima, aunque al ser la última (resumen y conciliación) fue efectiva y cumplió con su función finiquitadora.

Mucho, muchísimo podríamos hablar aquí sobre esta controversia y sobre todas y cada una de las décimas que se improvisaron en todo el Campeonato (impresionante sobre todo la controversia entre el puertorriqueño Omar Santigago, el repentista extranjero que más lejos llegó en la competencia, y el carismático y siempre sorprendente Yordán Quintero, el «Yayito Ranchuelero»); pero terminaremos este acercamiento a lo acontecido en el Primer Campeonato de Pies Forzados «Cubadisco-Oralitura», desglosando y analizando uno de los momentos que más dio de qué hablar en la Final del evento. Una décima improvisada que fue de las más aplaudidas por el público, pero que, paradójicamente, le valió a su autor la puntuación más baja de la competencia, o, como dijera él mismo, sirvió para «descalificarme yo solo».

El pie forzado era «entre apagadas farolas», un verso de Rafael Alberti, y el poeta en cuestión fue el matancero Luis Quintana, no sólo uno de los grandes favoritos para ganar el certamen, sino uno de los mejores repentistas que ha dado Cuba en los últimos veinte años. Su décima es una décima que, con un error técnico grave, determinó la no permanencia del poeta en el concurso, pero que, asimismo, tuvo un impacto superlativo en el público y en el ánimo del propio repentista ${ }^{5}$. El pie forzado en cuestión pertenecía a la categoría de «pie forzado móvil» y el dado caprichoso quiso caer en el número 5 (quinto verso). Cantó entonces Quintana:

${ }^{5}$ He aquí otro de esos nudos gordianos que teje la improvisación. Ante una gran décima improvisada, ¿qué debe primar?, ¿la fuerza improvisadora y el ingenio?, ¿la ortodoxia técnica?, ¿el impacto en el público y el grado de eficacia?, ¿la rígida preceptiva del repentismo cubano? ¿De qué estamos hablando en este caso, de técnica, o de «tecniquerías», como diría Unamuno según Borges? Tómese en cuenta que en ningún otro país esta décima hubiera sido penalizada, ni descalificado su autor, sino al contrario. 
¡Estoy temblando a estas horas!

El miedo de no poder

un pie forzado vencer

en un juicio sin demoras.

Entre apagadas farolas,

mayoral del nerviosismo,

salta y rueda hasta el abismo

para que tú me lo traigas

que como quiera que caigas

yo voy a decir lo mismo.

El error técnico (grave, repetimos) está en las rimas de los versos 1, 4 y 5 (el pie forzado), es decir, el poeta viola una regla inviolable del repentismo cubano (la consonancia perfecta) al rimar «horas» y demoras» con «farolas». Lo más curioso de este caso es que el propio Luis Quintana, un repentista de tal dominio técnico que si yo no hubiera estado allí, no lo hubiera creído («a estos niveles no sucede esto», decía yo en las reuniones previas); el mismo poeta, repito, no se dio cuenta del error hasta que, entre aplausos y vítores, ya sentado entre el público, un compañero suyo se lo dijo. Y es más llamativo porque Luis Quintana es de los pocos repentistas cubanos que ha hecho un arte del equívoco; el único que ha asumido la falibilidad textual como lo que es, una característica inherente al habla, y por lo tanto, natural, siendo capaz, incluso, algo que hace con mucha frecuencia, de rectificar una décima y volver a empezarla, esté cantando ya el verso que sea (yo lo he visto regresar desde el verso 8 y comenzar de nuevo). Pues bien, Luis Quintana en esta competencia tomó su pie forzado, lo elaboró, lo cantó, recibió los atronadores aplausos y bajó feliz y satisfecho del escenario, sin darse cuenta del evidente gazapo. Y es más significativo aún cuando uno ve otra vez las imágenes (igracias tecnología!, ; gracias, video!). Desde que la locutora tira el dado poético, lee públicamente el verso de Rafael Alberti y le entrega el papel con el pie escrito a Luis Quintana, hasta que éste comienza el primer verso de su décima, transcurre la «friolera» de 72 ss. (1 minuto y 12 segundos), posiblemente la arrancada más lenta de todo el Campeonato, algo poco común en el propio Quintana. Durante ese «largo» minuto Quintana estuvo todo el tiempo moviéndose como un león enjaulado (me encanta la exactitud de este manido símil en estos casos) detrás del micrófono, con el 
papel escrito en una mano, armando su décima, y aún tuvo tiempo de llamar a la presentadora para que le entregara el dado poético, y cantar con él en la otra mano. Y aquí me detengo otra vez, con perdón, porque ésta es una actitud significativa y pieza clave en los acontecimientos. Quintana pide el dado, tiene ese detalle a priori, pedir el dado, por lo tanto, ya él sabe antes de empezar su décima cómo va a terminarla, lo que va a hacer, un golpe teatral efectivo y efectista, que se aleja de su estilo pero que, en una competencia, es legítimo y válido. No por gusto yo mismo lo escuché decir más de una vez en todo el campeonato, «este concurso es otra cosa, esto es distinto». Convencido de que tanto a ese público (capitalino, no asiduo al repentismo), como a ese jurado (¡ese polémico jurado!) había que ganárselos no sólo a golpe de «décima buena», Luis Quintana preparó un «golpe mortal», teatral y efectista, metacompetitivo, usando las mismas herramientas con que le obligaban a combatir: un dado y un pie forzado. Es llamativo también que en este tiempo previo Quintana releyó el pie forzado por lo menos tres veces. Así las cosas, con el pie forzado en una mano y el dado en la otra, el poeta comienza su décima:

\section{¡Estoy temblando a estas horas! \\ El miedo de no poder \\ un pie forzado vencer \\ en un juicio sin demoras.}

Destaquemos aquí que el poeta respetó la cesura opcional tras el segundo verso, permitió un corto interludio, los repitió y completó su redondilla, es decir, que no estaba apurado, estaba tranquilo y seguro. Ya en el entrada del puente, no respetó la cesura obligatoria, sino que hizo una levísima inflexión respiratoria y se lanzó «sin pensar» hacia el puente y la segunda redondilla, seguro de su final y de su éxito, sin reparar en ningún momento en que ya, desde el verso primero (rima «-oras») su décima estaba condenada, porque el quinto verso ( $¡$ el pie forzado!) terminaba en «-olas». Con una ínfima pausa y mucho ímpetu Quintana sigue su décima:

\section{Entre apagadas farolas,}

$$
\text { mayoral del nerviosismo... }
$$

Pero aquí hay todavía una curiosidad mayor, una sorpresa mayúscula. Cuando vemos las imágenes nos percatamos de que el poeta canta el quinto verso, el pie en cuestión, ¡leyéndolo!... iy no se da cuenta del cambio de ri- 
mas! Continúa improvisando, eso sí, con el mejor hallazgo poético de toda la estrofa, cuando señala al dado que tiene en la mano y lo rebautiza como «mayoral del nerviosismo», un vocativo que se saca de la manga y que contextualiza muy bien lo que dice y secunda la metacompetitividad de su discurso. Finalmente remata, lanzando el dado al aire, con histriónico desdén:

salta y rueda hasta el abismo ${ }^{6}$

para que tú me lo traigas

que como quiera que caigas

yo voy a decir lo mismo.

Esta décima, repito, es excelente, y todos los que estábamos allí aplaudimos la habilidad, el ingenio, la destreza lingüística y teatral del repentista. Llamo la atención, finalmente, en dos cosas: primero, que Luis Quintana demostró una vez más en esta décima que es uno de los repentistas cubanos que mejor domina el lenguaje kinésico, ya que todo su discurso estuvo apoyado por gestos enfáticos tremendamente fértiles; y segundo, que el poeta, que había tardado aquellos «largos» 72 segundos en comenzar su décima, sólo tardó 42 segundos en enunciarla, lo que demuestra por una parte la importancia del tiempo previo, y por otro, la efectividad del modo de elaboración por bloques inversos.

Ha pasado un mes ya de la competencia. Si me preguntan ahora cuál es mi hipótesis (que siempre será eso, hipótesis) para este impensable error de Luis Quintana, diría que, por una parte, un exceso de confianza en el orden estructural de la décima; por otra, el hecho de que el poeta, no ducho en histrionismos de este tipo, tal vez estaba demasiado pendiente del trabajo de edición para «encajar bien» el juego de rimas «aigas»e «ismo» de su final; y por otra, la presión que significa toda competencia, obraron el milagro de que uno de nuestros mejores repentistas actuales mirara sin ver, oyera sin escuchar, rimara sin rimar y no se diera cuenta.

Permítanme, antes de terminar, detenerme un poco en esta décima, en su texto, porque vale la pena. Para empezar, no pasemos por alto que Quintana se «divorcia» del pie forzado (nada de farolas, ni de oscuridades) y que elabora una décima metacompetitiva, autoreferencial, donde los protagonistas

${ }^{6}$ Este verso es una reminiscencia, inconsciente, por supuesto, del clásico verso de Ficho Guía: «rueda el ave hacia el abismo». 
son el dado poético y el propio pie forzado. Desde el primer verso hace una alusión contextualizadora. En su décima anterior Quintana había sido el único concursante en reconocer públicamente que estaba nervioso. Por eso dice ahora «Estoy temblando a estas horas», elemento circunstancial de indudable impacto en los oyentes. En el segundo verso habla de «miedo» y en el tercero habla directamente del «pie forzado». Luego, encaja el verso ajeno, pero sin darle peso semántico alguno, encaja éste como pudiera haber encajado otro cualquiera; «entre apagadas farolas» se convierte así en una abstracción (¿se refiere a las luces del teatro apagadas?), lejos de las concretas farolas de Alberti y de sus posibles farolas concretas de Quintana, si hubiera seleccionado otro estilo de décima, la argumental o anecdótica (para lo que se prestaba, fácilmente, el verso). Pero no. El poeta ha preferido un discurso metacompetitivo, metapoético y en este caso el verso es eso, un verso, no una idea, pesa sintácticamente mucho más que en el plano semántico. Para completar su estrategia, Quintana individualiza (y personaliza), en el mejor hallazgo de toda la estrofa, al caprichoso dado, y, con un golpe poético de magia, lo convierte en «mayoral» (el dado manda), en «mayoral del nerviosismo» (el dado manda y es quien provoca los temblores del primer verso). Finalmente, luego de un verso en el que él, Quintana, supuestamente subalterno del mayoral Dado, le ordena a éste que «salte», que «ruede» (Quintana toma el mando) y que «le traiga» el pie forzado, remata con una elegancia y altanería aplastantes: «que como quiera que caigas / yo voy a cantar lo mismo». Es decir, nada. Porque Quintana no ha hecho caso al verso; nos ha engañado a todos, ha dicho sin decir, ha jugado con Alberti, con el pie, con el jurado y con nosotros, los oyentes. «Entre apagadas farolas» no ha pasado nada; todo ha pasado entre encendidas palabras de un poeta hábil, malabarista de idioma y de los mecanismos de recepción del público. «Lo mismo», asegura Quintana, «yo voy a decir lo mismo», alardea, «como quiera que caigas», mirando de reojo al dado y de frente al público. ¿Quiere esto decir que si sale el número 5, como ocurrió, o sale el 10 , el 4, el 1, el poeta hubiera dicho «lo mismo»? Sabemos que no, la estructura hermética de la décima lo impide, pero Quintana tiene la habilidad de hacer parecer que sí, que lo haría, y nos convence hasta el aplauso. He aquí la magia de la improvisación. He aquí lo que puede lograr un repentista con su pirotecnia verbal, con su dominio del espacio comunicativo. A esto, los antiguos griegos, con respeto mayúsculo, le llamaban, «retórica». Y los grandes artistas de la retórica, los Demóstenes y compañía, eran venerados como rhetér epéon (López Eire, 1997). Sin ninguna duda, Luis Quintana es un consumado rhetér epéon. 
Hasta aquí este acercamiento al mundo pintoresco de los pies forzados, y al amplio y mágico ámbito de la oralidad poética, de la Oralitura, el moderno y la vez antiguo arte de los repentistas, troveros, cantautores, rappers, slammers, etc., una forma de hacer poesía que ha sobrevivido (y sobrevivirá) al paso de los tiempos, las modas, los estilos de vida, las tecnologías, e incluso, las indiferencias sociales, ya sean mediáticas, industriales o académicas.

\section{REFERENCIAS BIBLIOGRÁFICAS}

ARMISTEAD, S. G. (1994). «La poesía oral improvisada en la tradición hispánica». En La décima popular en la tradición hispánica. Actas del Simposio Internacional sobre la Décima, M. Trapero (ed.), 41-69. Las Palmas de Gran Canaria: Universidad de las Palmas de Gran Canaria /Cabildo Insular de Gran Canaria.

BROUWER, L. (1989). La música, lo cubano y la innovación. La Habana: Editorial Letras Cubanas.

DÍAZ-PIMIENTA, A. (1995). «Primeros apuntes para un estudio del repentismo en Cuba». En La décima popular en Iberoamérica, 239-252. Veracruz: Instituto Veracruzano de Cultura.

- (1997). «Para una metodología de la enseñanza de la improvisación». Ponencia leída en el V Festival Iberoamericano de la Décima. Las Tunas, Cuba.

- (1998). Teoría de la improvisación. Primeras páginas para el estudio del repentismo. Guipúzcoa: Sendoa.

- (2003). Cómo nace un repentista. Metodología para la enseñanza de la improvisación poética. La Habana: Imprenta del Palacio de las Convenciones.

- (2004). «Sobre la dinámica interna de la improvisación poética». En Improvisación oral en el mundo (Actas del Encuentro celebrado en Donostia entre el 3 y 8 de noviembre de 2003), 63-114. Donosti-Bilbo: Euskal Herriko Bertsozale Elkartea.

FERRERO, A. (2010). «Yo sí plagié». En http://noticiastransmedia.com/index.php/2010/06/19/yo-si-plagie/.

LÓPEZ EIRE, Antonio (1997). Retórica clásica y teoría literaria moderna. 
Cuadernos de lengua española. Madrid: Arco/Libros.

SÁNCHEZ ROMERALO, A. (1989). «Presencia de la voz en la poesía oral». En El Romancero. Tradición y pervivencia a fines del siglo XX. Actas del IV Coloquio Internacional del Romancero, P. M. Piñero et al. (ed.). Sevilla-Cádiz: Fundación Machado-Universidad de Cádiz.

TRAPERO, M. y LLAMAS, E. (1997). «De la voz a la letra: Problemas lingüísticos en la transcripción de los relatos orales. I: la puntuación». $R e$ vista de Dialectología y Tradiciones Populares, tomo LII, 43-44.

VIGARA TAUSTE, A. M. (1992). «Recursos lingüísticos de incorporación contextual al enunciado: deíxis situacional». En Morfosintaxis del español coloquial. Esbozo estilístico, 347-375. Madrid: Gredos.

ZUMTHOR, P. (1991). Introducción a la poesía oral. Madrid: Taurus.

Recibido el 7 de julio de 2012.

Aceptado el 17 de septiembre de 2012. 
